\title{
The development of coeducation in Poland against European backdrop (19th-21st century)
}

\author{
Katarzyna Dormus ${ }^{1, *}$ \\ ${ }^{1}$ Pedagogical University of Cracow, Podchorążych 2, 30-084 Kraków, Poland
}

\begin{abstract}
The goal of the paper is to shed light on the problem of coeducation on a Poland in the European backdrop in 19th-21st century. An excellent source for the analysis of this topic is, in particular, the 19th- and 20th- century pedagogical and female press, documents of educational authorities, school reports. Results and conclusion: During the late 19th and early 20th century, coeducation was - in all of Europe - a source of controversy, resulting in a public discussion. The first coeducational secondary schools in the Polish territories were established over the course of the First World War. Coeducation was widely adopted after the Second World War, but the question of whether coeducation brings more benefits or drawbacks remains open for debate.
\end{abstract}

\section{Introduction}

Today, coeducation is the dominant arrangement in Europe across all stages of education, from pre-school to university. It has become a widely accepted phenomenon, even though the history of co-educational schools, especially on a secondary level, is relatively short and has been accompanied by an ongoing debate, which has been gaining momentum again over the past years. The analysis of the phenomenon, that is, the functioning of coeducational schools and the dispute regarding coeducation, is interesting due to the fact that it reflects not changes not only within the educational sphere but also within the social aspect and customs. As exemplified by Poland, the shifting approach towards mixed-gender schools (on secondary level in particular) in Europe between the $19^{\text {th }}$ until the 21 st century is clearly visible.

Primary sources used to depict the development of coeducation in Poland consist of publicist articles and compilations released in the first half of the 20th century. Except for several articles, this subject matter has not yet been discussed in detail by Polish academic literature [8, 39]

\section{$219^{\text {th }}$ century}

In the United States and Europe, coeducation began to be implemented on a large scale (beginning with the elementary level) in the 19th century for financial and organisational reasons. In Europe, coeducational elementary schools were no novelty; they have been in

\footnotetext{
*Corresponding author: kdormus@,op.pl
} 
operation throughout the modern era. Examples include Casa Giocosa run by Vittorino da Feltre in the 15th-century Mantua or 16th-century Lutheran parish schools in which boys and girls attended separate classes [18]. Pursuant to Luther's guidelines, they thus preferred "soft coeducation."

The spread of education ongoing since the late 18th century triggered organizational and economic problems regarding operation of existing and launching new elementary schools. In the 19th century, popularisation of coeducation at this level was undoubtedly accelerated by adoption of compulsory education by several European governments. The first, barely successful, attempts were made in Prussia. Back in the day, educational policies of many European states aimed at including as many children as possible into the educational system [16] and implementation of coeducational schools facilitated and accelerated the process. It was far easier and cheaper to manage a single classroom shared by boys and girls than to provide two separate ones.

The first country to embrace coeducation at all levels of education was the United States $^{2}$. Such a system best reflected the principles of freedom and equality of all citizens which stemmed both from the core of their system of values but also from their pragmatic approach to reality. The advantages of coeducation were summed up by the American philosopher and educator, William Torrey Harris (1835-1909), who argued that it brings forward economic, educational, moral, and social benefits, reflecting family-type of relationships, ensuring equal treatment of both sexes, and, finally, having a favourable effect on the discipline and moral development of young people [6, 22, 23, 24].

In Europe at the dawn of the 19th century, implementation of coeducation met some resistance and the system did not gain a prevailing position. Coeducation was perceived differently depending on the level of education. At the elementary level, coeducation was a common practice due to its practical aspects, while the fact that prepubertal children of both sexes spent time together did raise concerns of moral and ethical nature. There was no debate on whether coeducational university programmes (when women started to be admitted)was reasonable, because it seemed pretty obvious that having double university structures - separate for men and women - posed serious problems or was hardly feasible.

A heated dispute was triggered by introduction of coeducation at secondary level. This issue arouse most fervent interest from two circles in particular - women's organizations and teachers, although medical doctors and clergymen also voiced their opinions eagerly. Controversy around the introduction of coeducation into secondary schools resulted from the fact that they were attended by adolescents, who, according to general opinion, required particularly vigilant care from their educators. The debate, arguments relating to the worldview and customs, as well as of social, psychological, and medical nature were raised.

A crucial factor affecting the tone of that debate was the changing social situation of women. The development of capitalist economy resulted in increasing numbers of females who were forced to seek employment. The issue of gaining proper education and qualifications seemed crucial. Also, women's educational aspirations rose due to the development of the female movement in numerous European countries of that era [33]. Coeducation became one of the movement's core postulates as a way to reduce the harmful difference between the educational system for boys and girls.

The European way of thinking about education was also affected by positivism, in particular, its postulates of making education available to the widest possible social circles $[8,14]$. Other sources of inspiration included information for the United States on the developing American coeducational system. At the turn of the 19th and 20th century, a huge role was played by reformatory pedagogical currents labelled jointly as "the new

\footnotetext{
${ }^{2}$ All $19^{\text {th }}$ century American primary schools were coeducational, while the first coeducational secondary school was launched in 1833 in Oberlin, Ohio.
} 
education"3, which proposed introduction of changes into the existing ways of teaching and education for the new generation. Representatives ${ }^{4}$ of "the new education" shared a belief that a child should become the subject of an educational process, which must take the child's metal characteristics as well as individual needs and interest into consideration and create opportunities for creative activity [9]. Under the impact of this current, in Western Europe (mostly in France, England, Germany, and Switzerland), schools of the so called "new type" were launched as an alternative for existing schools. Some of these institutions were coeducational. The first coeducational "school of the new type" was Bedales in Petersfield, England, founded in 1893 by John Haden Badley [8].

However, Scandinavia was the first European region to introduce coeducation at the secondary level. In 1876, Europe's first coeducational secondary school was founded in Stockholm. In other European countries, coeducation was not progressing as rapidly. Catholic countries were particularly resistant to the idea. Therefore, coeducation was implemented hesitantly at the elementary level in Italy, France, Belgium, Spain, and Portugal. Protestant countries - the Scandinavian ones, Switzerland, or the Netherlands were characterized by a more liberal approach. In England of the 1890s, coeducational secondary schools began to be founded and some of them gained international recognition. In German-speaking countries, the separation of the sexes was preserved as much as possible in higher grades of elementary schools and coeducational secondary schools were still scarce. Prussia was the most hostile towards the idea of coeducation, which resulted from the anti-emancipation attitude exhibited by the Emperor and the ruling circles. Austria and Russia were very cautious about coeducation [6, 22, 24].

In Poland, similarly to other parts of Europe, coeducation existed in home schooling and girls began to be admitted to parish schools in the modern era [2].

When, by the end of the 18th century, Poland ceased to be an independent country and was partitioned by Russia, Austria, and Prussia, these political circumstances had a huge impact on the functioning of the educational system. Since that time, schools in a given partition operated within the legal and organisational system of the partitioner [3]. Differences in operation of these schools, the coeducational aspect included, depict the approach of various European stated to the problem.

In the Prussian partition, due to the conservativism of authorities, coeducational secondary schools were not launched. First such institutions were opened in late 1921, when Poland had already regained its independence [49]. In the Russian partition, the attempts to launch coeducational secondary schools were very modest and these were privately-owned schools only [31].

Austria was the most opened to change. In the school year of 1907/08, the Ministry of Education made an exception for several girls and allowed them to attend all classes except for physical education in an all-boy middle school in Wels. In 1910, an ordinance was passed, effective within the Austrian partition (Galicia) as well, that allowed girls to attend boys' middle schools as observing students, but only in towns where there were no separate grammar schools, higher education institutions, nor teacher colleges for females. Claiming the need to prevent overpopulation in classrooms, the number of visiting female students was limited to $5 \%$, and later to $10 \%$, of all students. Thus, the numbers of female students attending boys' middle schools were low, even though there were a number of applicants. Therefore, some secondary schools decided to launch special afternoon middle school

\footnotetext{
${ }^{3}$ In the United States, they were referred to as "progressivism", while in Germany they were called the "pedagogy of reform".

${ }^{4}$ Outstanding representatives of the "new education" included, among others, John Dewey, Edouard Claparède, Ovide Declory, Maria Montessori, Georg Kerchensteiner, Célestin Freinet.
} 
courses addressed at girls only or created separate all-female Realschule classes [6, 22, 25, 50].

Girls could attend these schools as observing students only, which meant they were allowed only to listen in class while they were not examined on regular basis and their homework was not marked, however they would take term and end-of-the-year finals covering all the material discussed throughout the course. Thus, coeducation did not in fact exist in Polish Galicia, since girls attending boy's schools did not enjoy equal rights with their male peers. They were allowed to study along boys on special terms, which in reality reduced their participation in class to hearing the lectures [25].

In the Austrian partition of the early 19th century, private coeducational schools began to come into existence. These usually were experimental institutions operating under the spirit of the "new education". One of the very first such schools was the Kraków-based Maria Ramultowa's school which operated in the years 1906-1918 [5, 6, 10, 32, 36].

The educational practice in the Polish territories was accompanied by a debate, which, since 1870s, took place mostly in pedagogical and women's magazines. Supporters of coeducation voiced their opinions most often, while publicists exhibited a strong fascination by American models [35, 42, 45]. Moreover, a number of arguments on coeducation questioned the common opinions on the differences between the natures of both sexes. We might thus claim that the debate concerned the bases of the social system to a larger extent than the pedagogical issues $[1,6,13,23,30]$.

Throughout the debate, various aspects of coeducation were discussed. For example, within the physiological and psychological aspect, the differences in the pace of physiological and mental development between adolescent boys and girls were considered [46]. Also the effects of coeducational system on shaping boys' and girls' personalities were discussed. Both the supporters and opponents of coeducation agreed that certain personality traits are assigned invariably to each sex. The question was whether the traits assigned to the male and female character are strengthened or weakened as a result of coeducation [4, 23, 24, 29, 43]. The aspect of customs stirred emotions, because questions of whether coeducation could jeopardise the foundations of the existing moral values were raised. The opponents of coeducation split into two groups of differing approaches to this problem. Some believed that coeducation leads to premature puberty and, as a result, to exuberant eroticism [13], while the other group of opponents of coeducation was certain that it results in indifference and loss of mutual sense of attractiveness [4]. The supporters, on the other hand, claimed that sharing the learning and play experience at school reflects the reality of family and extra-school life, which may lead to normalisation of mutual relations between boys and girls, promoting friendship rather than excessive eroticism [7, 28].

\section{The interwar period (1918-1939)}

In the interwar period (1918-1939), the issue of coeducation at the secondary level was still approached with a great deal of reserve, although the number of coeducational secondary schools was increasing. In Catholic countries, the Catholic Church had a significant impact on the situation, which was reflected in Pope Pius XI's encyclical of 1929, "Divini Illius Magistri", in which coeducation was denounced as contradictory to the principles of Christian upbringing [34]. One of Poland's greatest opponents of coeducation, primate cardinal August, believed it to be a dangerous phenomenon driving laicization of the educational system [19].

World War I brought Poland's independence. In November 1918, a sovereign Polish state (the Second Republic of Poland) came into being. The young country faced a difficult task of merging and rebuild structures of the educational system [3]. 
Within the new wartime and post-war circumstances, the debate on coeducation progressed. By the end of the war, the tome of arguments had changed a lot. Previously discussed aspects kept recurring, yet the negative attitudes to the issue of coeducation weakened, especially due to the change in women's situation and progress of equality of rights [26]. Undoubtedly, one of the factors driving public attention to the problem of secondary education for women was the fact that in 1920 colleges and universities opened up for female students [48].

The teachers also voiced their opinions. Their statements concerning coeducation became more toned-down, while previous impetuosity gave way to sensibility. Recommendations to precede implementation of coeducation with comprehensive study prevailed [13].

Yet, practice outran theoretical discussion. At the elementary level, coeducation was the dominating style, while the number of coeducation secondary schools was increasing. For a young and war-afflicted state, it was often extremely difficult to create separate structures of secondary schools for boys and girls with simultaneous increase in women's educational aspirations. In smaller cities and towns, the new intelligentsia wished to provide best learning environment for their children - both sons and daughters - and organized coeducational middle schools employing their own resources before any official regulations were passed. Circa 50 such coeducational schools came into existence during and immediately after the war [25].

Throughout that period, strange hybrids also occurred which "could not be classified as either boys', or girls' or coeducational schools, because classes corresponding to all three types existed within a single institution" [15].

At a later time, in 1930s in particular, the number of state-run coeducational secondary schools doubled and almost reached the number of boys' schools [40]. In the school year of 1937/38, out of 307 state-run middle schools, 123 were coeducational (40\%) and out of 297 grammar schools, 114 were coeducational (38.4\%). Within the public education sector, out of 462 middle schools, 176 were coeducational (38.1\%) and out of 366 grammar schools, 114 were coeducational (31\%) [37, 40, 51]. Among public coeducational middle schools, a large group was formed by schools run by religious and national minorities. Almost $1 / 4$ of them were Jewish schools [51]. A characteristic phenomenon consisted in the fact that coeducational secondary schools were located mostly in small cities and towns $[17,21,41$, 49].

Throughout the interwar period, male students dominated in secondary coeducational schools, which resulted mostly from the tradition urging to educate boys first [27]. The authorities consistently supported creation of boys' secondary schools. There were numerous locations having only one school and this was quite often an all-boy school [20].

Regarding the school's internal organisation, coeducational school did not always meet the conditions that would allow mixed-students' schools to operate as a well-thought pedagogical system [26]. These schools often struggled and their achievement levels were usually quite low [25]. This probably resulted from the fact that these schools were governed by economic reasons and a wish to enable students to access secondary education rather than and did not result from a well-thought implementation of a pedagogical system.

\section{Post World War II}

Significant changes occurred after World War II, when coeducation became a widespread educational practice, yet the debate on the advantages and disadvantages of a mixed-student system was still ongoing. Over the past years, it even grew stronger. The idea of single-sex education has been gaining in popularity In recent years, an increasing interest in this model has been observed, which translates into a growing number of educational institutions of 
this type and more intense academic studies [11] as well as initiation of a public debate on the subject, as reflected by the First International Congress on Same-Sex Education held in Barcelona in 2007 with participation of 500 representatives from 21 countries. In 2011, a similar third congress took place in Warsaw [47]. It is enough to search the Internet or browse through popular daily paper and magazines to find a considerable amount of opinions on the topic. Even a cursory analysis of these statements allows us to draw several interesting conclusions.

What differentiates the debate from the turn of the 19th and 20th century from the current one is the fact that initially it was the supporters of coeducation who most often voiced their opinions, while nowadays it's the opponents of such system. Although for the promoters of mixed-gender education, who set the tone of the discussion in late 19th and early 20th century, coeducation was a progressive and democratic idea which aimed at equalizing life opportunities of men and women, the current view is that this idea is anachronist and strengthens typical stereotypes on sexes, as well as favours discrimination. It leads to uniformisation of teaching methods and enforces behavioural model of one sex onto an entire group. Some of the participants in the debate argue that the current coeducational system prefers girls because they are better-behaved, while the ideal of a good student is modelled after a girl, whose behaviour is adopted as the effective norm. Others claim that boys are promoted both in schools and workplaces, while girls, just like women later on, face the phenomenon of the so called "glass ceiling". People reluctant towards coeducation also believe that coeducational schools favour aggressive behaviour among students, because a shift in the point of gravity from learning onto courting generates conflicts, especially when paired with emotional immaturity of young people and the existing psychological differences. They argue that, there are more cases of mental health issues in mixed-gender schools, while the students' learning achievements are poorer. They explain the prevalence of coeducational schools as a result of not only financial and organisational aspects, but also of the fact that the problem of gender differences is nowadays ignored in Poland as "politically incorrect". They also point to the fact that restoring the single-sex educational model fulfils the postulate of educational freedom because the parents must have a free choice of school for their children, while expanding the educational offer increases the country's sense of freedom from the point of view of its citizens.

The supporters of the mixed-gender system reply with claims that, for example, coeducational schools facilitate socialization of young people, while violence is characteristic for single-sex schools, all-boy ones in particular. They also argue that students of coeducational schools have poorer learning achievements because in Western Europe, where such studies have been conducted, these schools are, in general, state-run schools, while same-sex school are exclusive public schools for wealthy students.

Also the supporters of a compromise voice their opinion that a monopoly of single-sex schools is an extreme scenario and that students should have an opportunity to choose from single-sex or mixed school. Some participants in the discussion propose compromise solutions such as creating all-boy and all-girl classes within one school or teaching subject particularly marked by stereotypes, such as IT, mathematics, or chemistry, in single-sex groups. The phenomenon is sometimes referred to as "soft coeducation".

Moreover, it is worth emphasising that although implementation of coeducation in secondary schools arouse most controversy, nowadays the problem of single-sex education is examined from the primary level onwards $[12,38,44,52,53,54]$. 


\section{Conclusion}

The discussion on coeducation has proceeded for decades and is now placed on the margin of reflections and debates on school-related problems. Simultaneously, it reflects broader social and pedagogical problems, in particular, the changing approach to stereotypes related to social functioning of men and women. At the same time, the claims of both the supporters and opponents of coeducation must be perceived as a form of critical reflection on the existing reality of the school system and as an expression of a will to reform it.

\section{References}

1. Z. Balicki, Zasady wychowania narodowego [The Principles of National Upbringing] [in:] Księga pamiątkowa II Polskiego Kongresu pedagogicznego odbytego w dniach 1 i 2 listopada 1909 we Lwowie, ed. J. Kornecki, Lvov (1909)

2. K. Bartnicka, K. Dormus, A. Wałęga, Komisja Edukacji Narodowej 1773-1794 [Commission of National Education 1773-1794], I, Warsaw (2018)

3. K. Bartnicka, I. Szybiak, Zarys historii wychowania [An Outline of the History of Education], Warsaw (2001)

4. J. Benoni-Dobrowolska J., Dr Cecil Reddie a koedukacja [Dr Cecil Reddie and Coeducation], „Szkoła Przyszłości” no 6-8, 8 (1906)

5. R. Centnerszwerowa, O wspólnym obu płci kształceniu w Polsce [On Joint Education of the Two Sexes in Poland], „Reforma Szkolna, I, 1-2, 283-298 (1904)

6. R. Centnerszwerowa, O wspólnym obu płci kształceniu w szkole średniej [On Joint Education of the Two Sexes in Secondary School], Warsaw (1905)

7. J. Ciembroniewicz, Rozdział płciowy a wychowanie [Separation of the Sexes and Education], „Nowe Słowo”, 3, 59-62 (1904)

8. Dormus K., Koedukacja - teoria i praktyka na ziemiach polskich na początku XX wieku [Coeducation - Theory and Practice on Polish Territories in the Early $20^{\text {th }}$ Century], „Rozprawy z dziejów oświaty”, XLIII, 53-92 (2004)

9. J. Draus, R. Terlecki, Historia wychowania [The History of Education], vol. II: Wiek XIX i XX, Kraków (2010)

10. W. Dzierzbicka, Szkoła pracy [The School of Work] [w:] Eksperymenty pedagogiczne w Polsce w latach 1900-1939, ed. W. Dzierzbicka, S. Dobrowolski, Wrocław (1963)

11. B. Ecler-Nocoń., Dziewczęta i chłopcy, razem czy osobno? Dwie perspektywy postrzegania edukacji [Boys and Girls, Together or Separated?], „Studia z teorii wychowania, 1, 161-175 (2015)

12. Edukacyjna wolność zróżnicowana. Rozmowa z Josepem Marią Barnilsem [Diverse Educational Freedom. An Interview with Josep Maria Barnils], „Gość Niedzielny” no 42 (2008)

13. W. Górski., Myśli o przystosowaniu szkolnictwa polskiego do życia [Reflections on the Adaptation of Polish Educational System to Life]. (A lecture given at the first Congress of Polish Teachers in the Capital City of Warsaw on $5^{\text {th }}$ January 1917), Warsaw (1917)

14. J. Hulewicz, Sprawa wyższego wykształcenia kobiet w Polsce w wieku XX [The Issue of Women's Higher Education in Poland of the $20^{\text {th }}$ Century], Kraków (1939) 
15. K. Konarski, Dzieje szkolnictwa w b. Królestwie Kongresowym 1915-1918 [The History of the Educational System in the Former Congress Poland 1915-1918], Kraków (1923)

16. S. Kot, Historia wychowania [The History of Education], vol. II, Warszawa (1996).

17. R. Kotowski, Dziewczęta w mundurkach. Młodzież żeńska szkół średnich w Polsce w latach 1918-1939 [Girls in Uniforms. Female Students in Secondary Schools in Poland in the Years 1918-1939], Kielce (2013)

18. S. Litak, Historia wychowania [The History of Education], vol. I: Do wielkiej Rewolucji Francuskiej [Until the Great French Revolution], Kraków (2004)

19. J. Macała, Z dyskusji o szkole katolickiej w II RP [From the Debate on the Catholic School in the Second Polish Republic], „Polityka i Społeczeństwo”, 3, 66-74 (2006)

20. S. Mauersberg S, Komu służyła szkoła w Drugiej Rzeczypospolitej. Społeczne uwarunkowania dostępu do oświaty [Whom School Served in the Second Polish Republic. Social Conditions of Access to Education], Wrocław (1988)

21. T. Męczkowska, Koedukacja. Wskazania organizacyjne i wychowawcze [Coeducation. Organisational and Educational Guidelines], „Ogniwo”, 81, (1931)

22. T. Męczkowska, O szkołach mieszanych [On Mixed-Gender Schools], „Nowe Słowo” no 13, 308 (1902)

23. T. Męczkowska, Szkoły mieszane (Koedukacja) [Mixed-Gender Schools (Coeducation)], (1st ed.) Kraków (1906)

24. T. Męczkowska, Nauczanie wspólne [Joint Education] [in:] „Encykopedia wychowawcza", vol. VII, Warsaw (1909)

25. T. Męczkowska, Szkoły mieszane. Koedukacja [Mixed-Gender Schools. Coeducation], (2 ${ }^{\text {nd }}$ ed.) Kraków (1920)

26. T. Męczkowska, Zagadnienia koedukacji w teorii i praktyce [Problems of Coeducation. Theory and Practice], „Zrąb”, vol. 1, 46-676 (1933)

27. J. Miąso, Kształcenie dziewcząt w Drugiej Rzeczypospolitej [Education of Girls in the Secoond Polish Republic] [in:] Kobieta i edukacja na ziemiach polskich w XIX i XX w. Zbiór studiów pod red. A. Żarnowskiej i A. Szwarca, vol. II, part 2, Warszawa (1992)

28. I. Moszczeńska, Reformy w wychowaniu moralnym [Reforms in Moral Upbringing], Warszawa (1903).

29. S. Mus, W sprawie koedukacji [On Coeducation], „Przegląd Pedagogiczny”, 13-16 (1904)

30. J. Niemiec, Szkoły średnie nowego typu nowego typu [Secondary Schools of the New Type], Nowy Targ (1912)

31. J. Niklewska, Prywatne szkoły średnie w Warszawie 1905-1915 [Public Secondary Schools in Warsaw 1905-1915], Warsaw (1987)

32. K. Ostachiewiczowa, Nowe dążenia w wychowaniu. Wiek XIX i XX [New Goals in Education. $19^{\text {th }}$ and $20^{\text {th }}$ Century], Wilno (1914)

33. M. Perrot, Moja historia kobiet [My History of Women], Warsaw (2009)

34. Pius XI pope, Divini illius magistri, Warszawa (1999).

35. E. Prądzyński, O prawach kobiet [On Women's Rights], Warsaw. (1873)

36. M. Ramultowa, Próby polskiej szkoły nowego typu [Attempts of the Polish School of the New Type], Kraków (1912) 
37. Z. Ruta, Prywatne szkolnictwo średnie ogólnokształcące w Krakowie i województwie krakowskim w latach 1932-1939 [Private Academic Secondary Schools in the city of Kraków and Kraków province in 1932-1939], Kraków (1990)

38. O. Rutkowska, Nieedukacyjna koedukacja [Non-educational Coeducation], „Magazyn Familia", 1, (2008)

39. A. Samsel, Koedukacja w szkołach średnich w Polsce i na świecie w latach 19181939 - świadomy wybór czy zło konieczne [Coeducation in Secondary Schools in Poland and in the World in the Years 1918-1939. A Conscious Choice or Necessary Evil], „Przegląd Historyczno-Oświatowy”, 3-4, 79-87 (2004)

40. Stan liczebny szkolnictwa średniego ogólnokształcącego oraz zakładów kształcenia nauczycieli w Okręgu 1937 [Head Count of Acadmeic Secondary Schools and Teacher Training Institutions in the District 1937] „Dziennik Urzędowy Kuratorjum Okręgu Szkolnego Krakowskiego”, 11, (1937)

41. Statystyka szkolnictwa 1937/38 [Statistics of the Educational System 1937/38], Warsaw (1939)

42. A. Szczepański, Szkoła i wychowanie w Polsce. Przegląd historyczny od najdawniejszych do najnowszych czasów [School and Education in Poland. A Historical Outline from the Earliest Times until the Contemporary], Poznań (1873)

43. A. Szycówna, Sprawa koedukacji w świetle psychologii dziecięcej [The Problem of Coeducation in the Light of Child Psychology], „Nowe Słowo” 9, 193-199 (1903)

44. K. Święcicka, Upadek Tomka Sawyera [The Fall of Tom Sawyer], „Kobieta” an insert for „Newsweek” magazine no 18 (2009)

45. A. Świętochowski, a series of articles Nowe drogi [New Ways] in „Przegląd Pedagogiczny” 1874 [in:] Źródła do dziejów wychowania i myśli pedagogicznej, ed. S. Wołoszyn, , vol. II. Kielce (1997).

46. B. Trzaskowski, Różnice w duchowym usposobieniu młodzieży szkolnej męskiej a żeńskiej [Differences in the Spiritual Nature of Male and Female Schoolchildren], „Muzeum” (1904)

47. III Międzynarodowy Kongres Edukacji Zróżnicowanej, , ed. Maria Skibińska, Warszawa (2011)

48. Ustawa 1920 [Act on Academic Schools of 1920], http://prawo.sejm.gov.pl/isap.nsf/DocDetails.xsp?id=WDU19200720494.

49. S. Walasek, Szkolnictwo średnie ogólnokształcące na ziemiach polskich w latach 1914-1923 [Secondary Academic Education in Polish Territories in the Years 19141923], Acta Universitatis Wratislaviensis No 1843. Prace Pedagogiczne CXII, Wrocław (1996)

50. Wspólne wychowanie chłopaków i dziewcząt [Joint Education of Boys and Girls]. Rektor K.E. Palmgren. „Szkoła Przyszłości”, 9-12, 9-16, (1906)

51. Wykaz państwowych i prywatnych szkół średnich ogólnokształcących, zakładów kształcenia nauczycieli oraz kursów dokształcających 1938. [List of State-Run and Public Secondary Academic Schools, Teacher Training Colleges, and Skills Improvement Courses 1938]. „Dziennik Urzędowy Kuratorjum Okręgu Szkolnego Krakowskiego" no 8 (1938)

52. http://www.wprost.pl/ar/44158/Szkolny-apartheid/

53. www.wysokieobcasy.pl/wysokie-obcasy/1,96856,3294474.html

54. www.misjarodzinna.pl/New/Edukacja_zroznicowana.pdf 